\title{
An Evaluation of Taxonomic Criteria in Streptomycetes on the Basis of Deoxyribonucleic Acid Homology
}

\author{
By M. OKANISHI, H. AKAGAWA AND H. UMEZAWA \\ Department of Antibiotics, National Institute of Health \\ Kamiohsaki, Shinagawa-ku, Tokyo, Japan
}

(Accepted for publication I4 March 1972)

\begin{abstract}
SUMMARY
Deoxyribonucleic acid (DNA) homologies of 57 cultures of Streptomyces, with emphasis on those within the so-called Griseus group, were studied in relation to other taxonomic features used for Streptomyces. The DNA samples from the 25 species of the Griseus group, which commonly exhibited the I I features characteristic of S. griseus ISP 5236, showed homology values ranging from 38 to $104 \%$ with the DNA sample from $S$. griseus ISP 5236. Among them, five species showed approximately $40 \%$ homology value and I 9 gave values of $56 \%$ or higher. The DNA homologies of 12 streptomycetes which differed from the cultures of the Griseus group in one or two of the I I selected features were also determined using $S$. griseus ISP 5236 DNA.

The genomic Griseus group was divided into six subgroups on the basis of the homology values with reference DNAs from Streptomyces griseus ISP 5236 and Actinomyces globisporus ISP 5I99. The DNAs of streptomycetes in the largest subgroup were found to be highly homologous to DNA from $S$. californicus ISP 5058 located in that subgroup. From the data obtained, the suitability of several diagnostic features as taxonomic criteria are discussed.
\end{abstract}

\section{INTRODUCTION}

Since Waksman \& Lechevalier (1953) proposed the group-species concept in the grouping of Streptomyces, many systems for differentiating the groups or species which include the taxon Streptomyces griseus have been proposed by Hesseltine, Benedict \& Pridham (I954), Baldacci (I958), Mayama (I959), Flaig \& Kutzner (I960), Nomi (1960), Baldacci, Locci, Farina \& Vegetti (1963), Pridham (1958, I964), Pridham \& Lyons (1965), Hütter (1967), and Gordon \& Horan (I968). The criteria in their systems are mainly based on personal experience and not on any phylogenetic evidence. It has not been determined whether phenetic similarity shown by the few characteristics accurately reflects the degree of genetic relatedness (De Ley \& Friedman, 1964). Genetic knowledge about bacteria is accumulating in support of the concept of a 'genetic species' or 'genospecies' (Ravin, 1963), which is opposed to the current practice of splitting genera into many species on the basis of only small phenotypic differences (Friedman \& De Ley, 1965).

Recently, a series of studies evaluating the reproducibility of taxonomic criteria in Streptomyces was undertaken co-operatively under the International Streptomyces Project (Gottlieb \&Shirling, 1967). Three hundred cultures were examined (Shirling \& Gottlieb, 1968 $a, b ;$ 1969) on standardized media by means of the criteria and methods described by Shirling \& Gottlieb (1966). Fairly high reproducibility of observations of the selected features was obtained with almost all of the cultures tested. However, no attempt has yet been made to combine or 
Table I. Organisms and the sources, except for streptomycetes identified by their ISP number

Organism

Streptomyces bikiniensis At-1 54

S. griseinus At-14

S. griseinus At-15

S. griseus At-I

S. griseus At-2

S. griseus at -437

S. griseus var. rhodochrous At-17

S. griseus var. rhodochrous At-20

S. olivaceus At-I I I

S. olivaceus $\mathrm{KCC}-67$

S. rameus At -363
Source

$$
\begin{aligned}
& \text { IMRU 35I4 } \\
& \text { NIHJ 0-60 } \\
& \text { NIHJ O-I } 8 \\
& \text { NIHJ S-I } \\
& \text { NIHJ S-2 } \\
& \text { ATU } \\
& \text { NIHJ SM-2 } \\
& \text { NIHJ SN-I4 } \\
& \text { NRRL B-I I } 25 \\
& \text { MTHU 27 } \\
& \text { NIHJ I6I6-Z3 }
\end{aligned}
$$

IMRU: Institute of Microbiology, Rutgers State University, U.S.A.

NIHJ: Department of Antibiotics, National Institute of Health, Japan.

ATU: Department of Agricultural Chemistry, University of Tokyo, Japan.

NRRL: Northern Regional Research Laboratory, ARS Culture Collection and Investigations, U.S.A.

MTHU: Department of Bacteriology, Tohoku University, Japan.

divide species in that study. The DNA homologies among actinomycetes have been reported by several researchers (Yamaguchi, I967; Monson, Bradley, Enquist \& Cruces, 1969; Farina \& Bradley, 1970) and the methods used were discussed in a previous paper (Okanishi \& Gregory, 1970).

In the present study, DNA homologies were used to study the Griseus group of Streptomyces, and the traditional criteria for identifying the Griseus group or the species in it were evaluated on the basis of the DNA homology values determined.

\section{METHODS}

Fifty-seven streptomycete cultures and a reference strain of Sarcina lutea were used. They included 46 cultures, designated by ISP numbers, obtained from the collection of the International Streptomyces Project through the Institute for Fermentation, Osaka (Japan). The features of these streptomycetes described in this paper were taken from the reports of the International Streptomyces Project (Shirling \& Gottlieb, I968 $a, b ;$ 1969). The designations and sources of the other II cultures are listed in Table I.

All streptomycetes were incubated at $27{ }^{\circ} \mathrm{C}$ in a minimal medium containing $\left.\mathrm{x} \cdot 5 \% \mathrm{w} / \mathrm{v}\right)$ glucose, $0.25 \%$ (w/v) asparagine (or $0.3 \%$ (w/v) glycine), $0.1 \%(w / v) \mathrm{NH}_{4} \mathrm{NO}_{3}, 0.05 \%$ (w/v) $\mathrm{MgSO}_{4} \cdot 7 \mathrm{H}_{2} \mathrm{O}, 0.02 \%(\mathrm{w} / \mathrm{v}) \mathrm{CaCl}_{2} .2 \mathrm{H}_{2} \mathrm{O}, 0.2 \%$ (v/v) trace element solution (Okanishi \& Gregory, 1970 ), $0.2 \%(w / v) \mathrm{KH}_{2} \mathrm{PO}_{4}$, and $0.4 \%$ (w/v) $\mathrm{Na}_{2} \mathrm{HPO}_{4} \cdot \mathrm{I}_{2} \mathrm{H}_{2} \mathrm{O}$. Sarcina lutea was incubated at $27^{\circ} \mathrm{C}$ in a Difco nutrient broth supplemented with $0.5 \%$ (w/v) $\mathrm{NaCl}$ and $0 . \mathrm{I} \%(\mathrm{w} / \mathrm{v})$ glucose. Labelling of DNA with radioisotopes $\left({ }^{3} \mathrm{H}\right.$ and $\left.{ }^{14} \mathrm{C}\right)$, and extraction and purification of DNA were carried out as previously described (Okanishi \& Gregory, 1970), except that the mycelia used for DNA extraction were incubated with pronase in the solution of $0.4 \%(\mathrm{w} / \mathrm{v})$ sodium dodecyl sulphate at $37^{\circ} \mathrm{C}$ for I h after the lysozyme treatment. The guanine-plus-cytosine content of each DNA preparation was determined by the depurination method of Huang \& Rosenberg (1966).

DNA-DNA hybridization was performed by the membrane-filter technique established previously (Okanishi \& Gregory, I970), with $30 \mu \mathrm{g}$ of sheared-denatured ${ }^{14} \mathrm{C}-$ labelled DNA (SD-DNA) and $2 \mu \mathrm{g}$ of immobilized ${ }^{3} \mathrm{H}$-DNA on a filter (IM-DNA). A filter bearing IM- 
DNA was incubated at $48^{\circ} \mathrm{C}$ for $20 \mathrm{~h}$ in a scintillation vial which contained $0.25 \mathrm{ml}$ of $23 \times$ normal strength SSC (SSC is $0.15 \mathrm{M}-\mathrm{NaCl}$ plus $0.015 \mathrm{M}$-sodium citrate), $0.5 \mathrm{ml}$ of formamide, and $0.25 \mathrm{ml}$ of SD-DNA (120 $\mu \mathrm{g} / \mathrm{ml}$ ). In a previous experiment (Okanishi \& Gregory, 1970), maximal hybridization required $40 \mathrm{~h}$ incubation but in the present experiment it was attained after $20 \mathrm{~h}$ incubation by using a vibrating incubator. At the end of the incubation period, each side of the membrane was washed with $30 \mathrm{ml}$ of double strength SSC in a conical sintered-glass filter by suction filtration. The filters were dried under an infrared lamp for $3 \mathrm{~h}$ and then ${ }^{3} \mathrm{H}$ - and ${ }^{14} \mathrm{C}$-radioactivities were counted in the two channels of a liquid scintillation counter (LS-200 B, Beckman Instruments, Inc., California, U.S.A.). The homology index of DNA was calculated from the amount of SD-DNA hybridized per unit of IM-DNA retained on a filter. Except for the determinations in Tables 2 and 3, the hybridizations were carried out with duplicate samples, and parts of the determinations were repeated twice. Results were expressed as an average of the determined values, and the values of standard deviation of each determination were lower than 3.0 .

\section{RESULTS AND DISCUSSION}

Reliability of the determination of DNA homology. The reliability was studied by determining the homologies of DNA from various isolates which were considered to belong to a single species on the basis of traditional taxonomic criteria and the identity of the antibiotic produced. The DNA sample derived from Streptomyces griseus ISP 5236 was used as SDDNA in this hybridization. The DNA homologies in streptomycin-producing $S$. griseus isolates ranged from 98 to $105 \%$; those of streptomycin-producing S. griseus var. rhodochrous cultures which were characterized by reddish purple vegetative mycelia were 77 and 8I \%; those of grisein-producing $S$. griseinus strains which differed from $S$. griseus in the utilization of L-arabinose and rhamnose ranged from 66 to $7 \mathrm{I} \%$ (Table 2). Table 2 also shows that if the homology value is calculated on the amount of SD-DNA hybridized, as most investigators have done in order to express the relative homology, errors result from variations in the amount of IM-DNA leached from the filters. These errors could be reduced by determining the amount of IM-DNA retained after the hybridization procedure and by calculating the amount of SD-DNA hybridized per unit of IM-DNA retained. It is apparent that the isolates identified as belonging to a single species have highly homologous DNA, indicating that the assay technique employed is reliable.

Furthermore, DNA-DNA hybridization was studied between Streptomyces griseus ISP 5236 and nine streptomycetes distinctly different from $S$. griseus. The majority of these streptomycetes, including species producing antibiotics of the streptomycin group, showed only approximately $40 \%$ homology with the test culture (Table 3 ). A DNA sample from Sarcina lutea, which has the same guanine-plus-cytosine content as the DNA of streptomycetes, showed only $5 \%$ homology. These facts suggest that $40 \%$ of DNA in an individual organism may be common to all species within the genus Streptomyces.

DNA homology of streptomycetes related to Streptomyces griseus and traditional taxonomic criteria. Twenty-five streptomycetes were selected from the species described in the International Streptomyces Project by means of the following taxonomic criteria which characterize Streptomyces griseus: spore-chain morphology is rectiflexibilis, spore surface is smooth; colour of aerial mycelium belongs to the yellow or red section; melanoid pigments are produced in neither peptone-yeast iron agar nor tryptone-yeast broth; D-glucose, D-xylose, D-mannitol, and D-fructose are utilized for growth; sucrose, $i$-inositol, and raffinose are not utilized. The streptomycetes which were identical in these I I properties characteristic of 
Table 2. DNA-DNA hybridization of isolates classified as Streptomyces griseus and $S$. griseinus with $S$. griseus ISP 5236

(A)

IM-DNA $^{a}$ retained

Source of IM-DNA
(B)

SD-DNA ${ }^{b}$

hybridized

$(\mu \mathrm{g})$
(C)

$\mathrm{B} / \mathrm{A} \times 100$

$74 \cdot 8$
$73 \cdot 2$
$76 \cdot 1$
$77 \cdot 3$
$78 \cdot 6$

$74 \cdot 8$

$1.252(100)^{\circ}$

$1.012(8 \mathrm{I})$

$1 \cdot 104(88)$

I·270 (96)

I. 238 (99)

$1 \cdot 383$

I.644

I. 575

SM-producing $S$. griseus var. rhodochrous. $\mathrm{VM}^{f}$ (reddish purple)

$\begin{array}{lllll}\text { At-17 } & 1.577 & 0.906(72) & 57 \cdot 5 & 77 \\ \text { At-20 } & \text { I.57I } & 0.946(76) & 60 \cdot 2 & 81\end{array}$

Grisein-producing S. griseinus. Ara $^{g}(+), \mathrm{Rha}^{h}(+)$

$\begin{array}{lllll}\text { ISP 5047 } & \text { I. } 438 & 0 \cdot 713(57) & 49 \cdot 6 & 66 \\ \text { At-I4 } & \text { I.144 } & 0 \cdot 613(49) & 53 \cdot 6 & 7 \text { I } \\ \text { At-15 } & \text { I.590 } & 0.787(63) & 49 \cdot 5 & 66\end{array}$

${ }^{a}$ IM-DNA: immobilized ${ }^{3} \mathrm{H}-D N A$ on a filter. ${ }^{\circ} \mathrm{SD}-\mathrm{DNA}$ : sheared-denatured ${ }^{14} \mathrm{C}-\mathrm{DNA}$. ${ }^{\mathrm{C}} \mathrm{SM}$ : streptomycin. "Actinomyces streptomycini Krasil'nikov. ${ }^{e}$ Relative amount of the reassociated SD-DNA against that in the homologous hybridization is given in parenthesis. ${ }^{f} \mathrm{VM}$ : vegetative mycelium. ${ }^{g} \mathrm{Ara}$ : utilization of $\mathrm{L}$-arabinose. ${ }^{h}$ Rha: utilization of rhamnose.

Table 3. Homology between DNA from streptomycetes clearly different from Streptomyces griseus and DNA from S. griseus ISP 5236

\begin{tabular}{|c|c|c|c|c|}
\hline Source of IM-DNA & $\begin{array}{l}(\mathrm{A}) \\
\text { IM-DNA } \\
\text { retained } \\
(\mu \mathrm{g})\end{array}$ & $\begin{array}{c}\text { (B) } \\
\text { SD-DNA } \\
\text { hybridized } \\
(\mu \mathrm{g})\end{array}$ & $\begin{array}{c}\text { (C) } \\
B / A \times 100\end{array}$ & $\begin{array}{c}\text { Homology } \\
\text { index }\end{array}$ \\
\hline tomyces griseus ISP $5236^{a}$ & $1 \cdot 674$ & I.252 & $74 \cdot 8$ & 100 \\
\hline ceus ISP 5072 & 0.858 & 0.315 & $36 \cdot 7$ & 49 \\
\hline aceus At-I I I & 0.916 & 0.343 & $37 \cdot 4$ & 50 \\
\hline vaceus $\mathrm{KCC}-67^{a}$ & $I \cdot 332$ & 0.418 & $31 \cdot 4$ & 42 \\
\hline iniensis At-1 $54^{a}$ & $1 \cdot 222$ & 0.512 & $41 \cdot 9$ & 56 \\
\hline midus ISP $5263^{a}$ & $1 \cdot 222$ & 0.357 & $29 \cdot 2$ & 39 \\
\hline eus At-363 ${ }^{a}$ & I $\cdot 25 \mathrm{I}$ & 0.347 & $27 \cdot 7$ & 37 \\
\hline Itensis ISP 504I & 1.530 & 0.459 & $30 \cdot 0$ & 40 \\
\hline $\begin{array}{l}\text { tezuelae ISP } 5230 \\
\text { toverticillium }\end{array}$ & $\mathrm{I} \cdot 597$ & 0.464 & $29 \cdot I$ & 39 \\
\hline carneum ISP $5004^{a}$ & $I \cdot 19 I$ & 0.356 & $29 \cdot 9$ & 40 \\
\hline na lutea & $\mathrm{I} \cdot 254$ & 0.047 & $3 \cdot 75$ & 5 \\
\hline
\end{tabular}

${ }^{a}$ Streptomycetes producing streptomycins.

S. griseus were used as a Griseus group in our experiments. Colour of vegetative mycelium, presence or absence of soluble pigments, and utilization of L-arabinose and rhamnose, were not taken as criteria for selecting the Griseus group because $S$. griseus var. rhodochrous and $S$. griseinus, which were different from $S$. griseus in the above properties, had provided fairly high homologies with the DNA of $S$. griseus ISP 5236 (Table 2).

Hybridization was attempted using DNA samples from the streptomycetes of the Griseus group and the DNA from Streptomyces griseus ISP 5236. As shown in Table 4, the DNA homology values of the 25 designated species ranged from 38 to $104 \%$. Among them, five species showed approximately $40 \%$ homology value and I9 gave values of $56 \%$ or higher. 
Table 4. Homology between DNA from streptomycetes of the Griseus group and DNA from Streptomyces griseus ISP 5236

Source of IM-DNA

Streptomyces griseus 5236

S. bikiniensis 5235

Actinomyces citreofluorescens 5265

S. ornatus 5307

S. lipmanii 5070

S. chrysomallus $5 \mathrm{I} 28$

A. vulgaris $520 \mathrm{I}$

A. fluorescens 5203

A. globisporus 5199

S. fimicarius 5322

A. badius $5 \mathrm{I} 39$

S. californicus 5058

S. pluricolorescens 5019

S. puniceus 5083

S. vinaceus 5257

S. albidus 5320

A. levoris 5202

S. alboviridis 5326

$S$. microflavus 533I

A. rubiginosohelvolus 5176

S. felleus $5 \mathrm{I} 30$

S. gougeroti 5324

$S$. intermedius 5372

S. sampsonii 5394

S. coelicolor 5233

S. rutgersensis 5077

$\begin{array}{cc}\begin{array}{c}\mathrm{G}+\mathrm{C}^{a} \\ (\%)\end{array} & \begin{array}{c}\text { Homology } \\ \text { index }\end{array} \\ 7 \mathrm{I} & \text { I00 } \\ 73 & \text { I04 } \\ 72 & \text { IOI } \\ 74 & 92 \\ 70 & 90 \\ 72 & 86 \\ 71 & 84 \\ 73 & 70 \\ 73 & 70 \\ 74 & 68 \\ 70 & 68 \\ 70 & 67 \\ 72 & 67 \\ 71 & 64 \\ 72 & 64 \\ 69 & 64 \\ \mathrm{ND} & 63 \\ 68 & 60 \\ \mathrm{ND} & 60 \\ 69 & 56 \\ 72 & 5 \mathrm{I} \\ 7 \mathrm{I} & 43 \\ 7 \mathrm{I} & 42 \\ \mathrm{ND} & 42 \\ 73 & 42 \\ 73 & 38\end{array}$

${ }^{a} \mathbf{G}+\mathrm{C}$ : guanine-plus-cytosine content.

${ }^{b} \mathrm{ND}$ : not done.

Table 5. DNA homology between Streptomyces griseus ISP 5236 and streptomycetes differing from $S$. griseus in one or two of the features used to define the Griseus group

\begin{tabular}{|c|c|}
\hline & Source of IM-DNA \\
\hline & Streptomyces griseus 5236 \\
\hline $\mathbf{I}$ & $\begin{array}{l}\text { Actinomyces daghestanicus } 5149 \\
\text { S. griseoviridis } 5229 \\
\text { S. roseochromogenus } 5463\end{array}$ \\
\hline II & $\begin{array}{l}\text { S. nigrifaciens } 5071 \\
\text { S. scabies } 5078 \\
\text { S. albidoflavus } 5455\end{array}$ \\
\hline III & $\begin{array}{l}\text { A. cyaneofuscatus } 5148 \\
\text { S. cavourensis } 5300 \\
\text { S. griseobrunneus } 5066\end{array}$ \\
\hline IV & $\begin{array}{l}\text { S. somaliensis } 5267 \\
\text { S. cellulosae } 5362 \\
\text { S. roseolus } 5174\end{array}$ \\
\hline
\end{tabular}

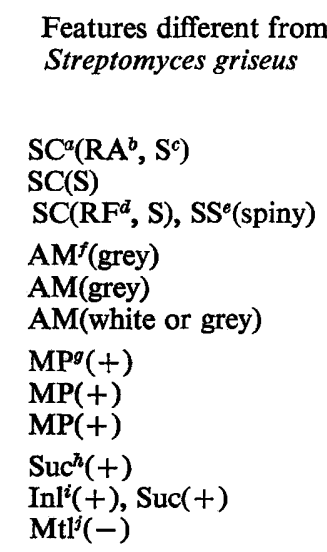
G+C Homology (\%) index $7 \mathrm{I} \quad 100$

$73 \quad 47$

$\begin{array}{ll}73 & 47 \\ 67 & 58\end{array}$

$\begin{array}{ll}70 & 58\end{array}$

$68 \quad 43$

$70 \quad 42$

$70 \quad 40$

$7 \mathrm{I} \quad 6 \mathrm{I}$

$\begin{array}{ll}72 & 67\end{array}$

$72 \quad 64$

$73 \quad 40$

$71 \quad 40$

$71 \quad 49$

${ }^{a} \mathrm{SC}$ : spore chain morphology. ${ }^{b} \mathrm{RA}$ : retinaculiaperti. ${ }^{e} \mathrm{~S}$ : spirales. ${ }^{a} \mathrm{RF}$ : rectiflexibiles. ${ }^{e} \mathrm{SS}$ : spore surface. ${ }^{f} \mathrm{AM}$ : aerial mycelium. ${ }^{g} \mathrm{MP}$ : formation of melanoid pigments. ${ }^{h}$ Suc: utilization of sucrose. ${ }^{i}$ Inl: utilization of $i$-inositol. ${ }^{i} \mathrm{M}$ tl: utilization of D-mannitol. 


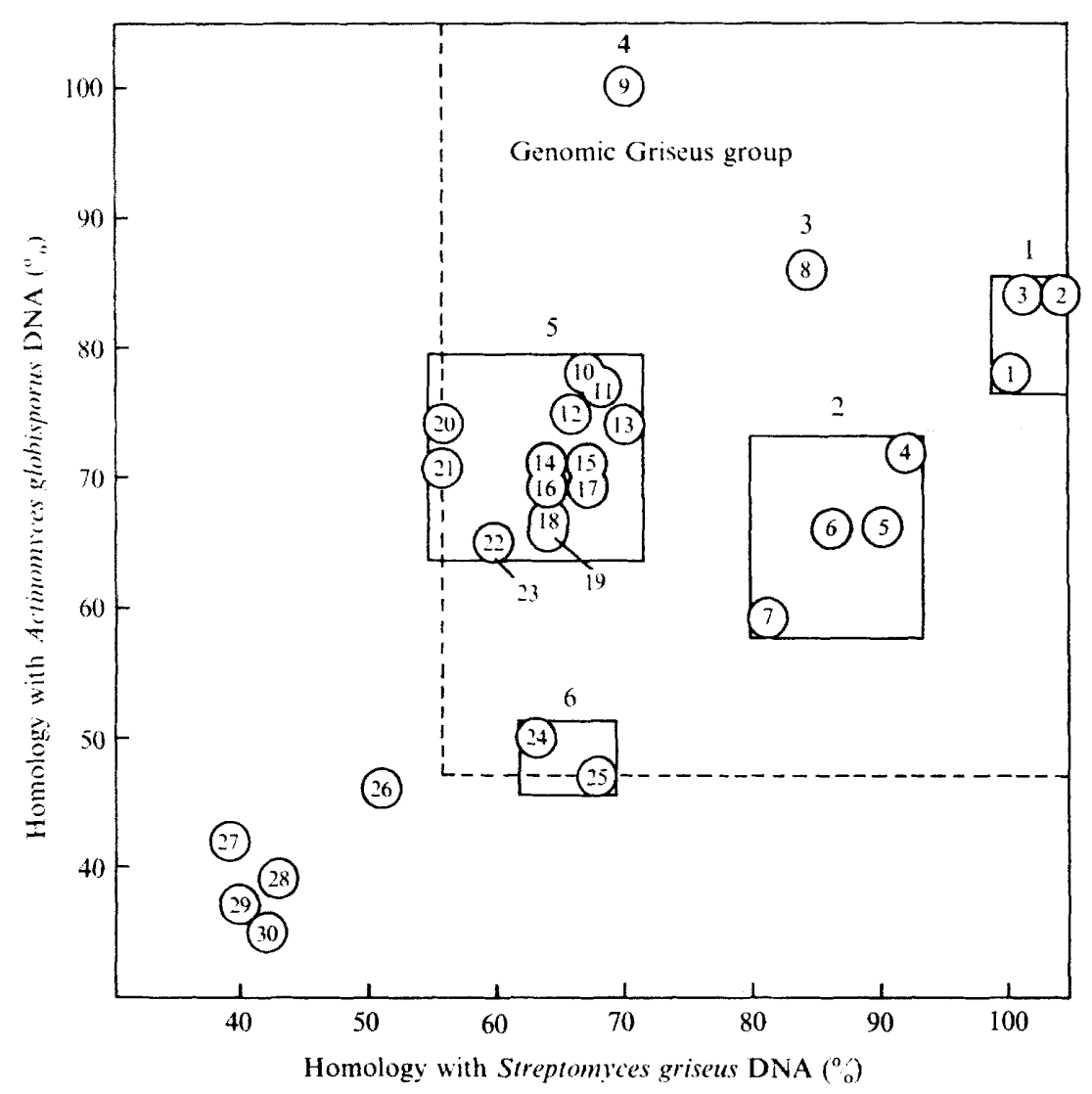

Fig. I. Diagrammatic grouping of streptomycetes in the Griseus group on the basis of DNA homologies obtained with reference DNAs from Streptomyces griseus ISP 5236 and Actinomyces globisporus ISP 5199. Each number in a circle identifies an individual type culture. The following list shows the designated species divided into the respective subgroups and indicates the properties of each culture which are different from those of $S$. griseus. Abbreviations used are: AM, aerial mycelium; VM, vegetative mycelium; SP, soluble pigments; Ara, utilization of L-arabinose; Rha, utilization of rhamnose; AB, type of antibiotic produced.

\section{Subgroup $\mathbf{I}$}

1. Streptomyces griseus ISP 5236

2. S. bikiniensis ISP $\mathbf{5 2 3 5}$

3. Actinomyces citreofluorescens ISP 5265: SP (yellow or green), Ara(+), Rha(+), AB (actinomycin C?)

\section{Subgroup 2}

4. Streptomyces ornatus 1SP 5307: SP (faint yellow), AB (ornamycin)

5. S. lipmanii ISP 5070: VM (yellow to yellow brown), Rha(t)

6. S. chrysomallus ISP 5128: SP (yellow), Ara(t), Rha(+), AB (actinomycin C)

7. S. griseus var. rhodochrous At-20: VM (reddish purple)

\section{Subgroup 3}

8. Actinomyces vulgaris ISP 5201: $\mathrm{Ara}(+), \mathrm{Rha}(+), \mathrm{AB}$ (pneumocin)

\section{Subgroup 4}

9. Actinomyces globisporus ISP 5199: SP (yellow to greenish yellow), Ara(+), Rha(+)

\section{Subgroup 5}

10. Streptomyces pluricolorescens isP 5019: AM (yellow or red), VM (yellow brown), Rha( + ), AB (pluramycin)

I I. Actinomyces badius ISP 5139: Ara( + )

12. S. griseinus ISP 5047: $\mathrm{Ara}(+), \mathrm{Rha}(+), \mathrm{AB}$ (grisein) 
The Griseus group used in our experiments was delineated by II common features and is more limited than the Griseus group described by other investigators. The range of the DNA homologies of the streptomycetes in this Griseus group, however, is too large to indicate that these cultures belong to a single species. A low homology value of approximately $40 \%$, which is equivalent to the DNA homology observed between the distinctly different species in the Streptomyces, was found in five of the 25 designated species. Generally, when DNA homologies and phenetic similarities are compared, agreement is good among strains of the same taxospecies (Jones \& Sneath, 1970). The results obtained indicate that the II properties are insufficient criteria for identifying the Griseus group, which is consistent with the DNA homology. Therefore, a group of streptomycetes having at least $56 \%$ homology with the DNA sample from $S$. griseus ISP 5236 was tentatively defined as the genomic Griseus group. The wide range of DNA homology values within this genomic Griseus group indicates that it may still consist of a mixture of different species.

The determination of DNA homologies was expanded to other streptomycetes which differ from Streptomyces griseus in one or two of the properties taken to define the Griseus group. DNA-DNA hybridization was tested between the DNA samples from these streptomycetes and the DNA from $S$. griseus ISP 5236. The DNA homologies of the melanoid pigmentproducing streptomycetes (group III) ranged from 6 I to $67 \%$ with S. griseus DNA (Table 5). All streptomycetes forming grey aerial mycelium (group II) and those differing from $S$. griseus in the utilization of D-mannitol, $i$-inositol, or sucrose (group IV) showed approximately $40 \%$ homology. Morphologically different streptomycetes (group I) resulted in intermediate homology values. These data suggest that the lack of formation of melanoid pigments would be of less value than the other properties in identifying the genomic Griseus group. The colour of aerial mycelium and utilization of three kinds of sugars, on the contrary, might be essential criteria for identification of the genomic Griseus group.

Subdivision of streptomycetes related to Streptomyces griseus. Theoretically, the DNA homology obtained by hybridizing with a single reference DNA is not enough to identify a species. Alternative hybridization was performed between the DNA samples from streptomycetes of the Griseus group and the DNA from Actinomyces globisporus ISP 5199, whose

13. A. fluorescens ISP 5203: SP (faint yellow), $\mathrm{Ara}(+), \mathrm{Rha}(+), \mathrm{AB}$ (actinomycin?)

I4. S. puniceus ISP 5083: VM (violet), SP (faint blue or violet), $\mathrm{AB}$ (viomycin)

15. S. californicus ISP 5058: AM (red), VM (violet or red), SP (violet or red), AB (viomycin)

I6. S. vinaceus ISP 5257: AM (red), VM (reddish purple), SP (red or yellow), AB (viomycin)

17. S. cavourensis ISP 5300: MP(+), VM (brown), Ara(+), AB (flavensomycin)

18. S. albidus ISP 5320: SP (greenish yellow), Rha( + )

19. S. griseobrunneus ISP 5066: MP( $(+)$

20. S. bikiniensis At-I54: very different

2I. A. rubiginosohelvolus isP 5176: VM (pale yellow), SP (yellow or greenish yellow), Ara $(+), \mathrm{Rha}(+)$

22. S. alboviridis ISP 5326: $\mathrm{Rha(}+$ )

23. S. microflavus ISP 533I: AM (grey or yellow), Rha( + )

Subgroup 6

24. Actinomyces levoris ISP 5202: $\mathrm{Ara}(+)$

25. Streptomyces fimicarius ISP 5322: AM (yellow or white), VM (reddish yellow), SP (red), Ara(+), Rha $(+)$

Miscellaneous group

26. Streptomyces felleus ISP 5I30: SP (faint yellow), $\mathrm{Ara}(+), \mathrm{AB}$ (picromycin)

27. S. venezuelae ISP 5230: very different

28. S. gougeroti ISP 5324: AM (white or yellow)

29. S. platensis ISP 504I: very different

30. S. intermedius ISP 5372: $\mathrm{Ara}(+), \mathrm{AB}$ (polyene) 
homology with Streptomyces griseus DNA was $70 \%$. Among the 30 designated species tested, the 25 species which showed at least $56 \%$ homology with $S$. griseus DNA showed $59 \%$ or higher homology with A. globisporus, with the exception of S. fimicarius and $S$. levoris (Fig. I). Streptomyces fimicarius and S. levoris showed only 47 and $50 \%$ homology, respectively, with $A$. globisporus DNA but their homology values with $S$. griseus DNA were 68 and $63 \%$, respectively. The four species which showed approximately $40 \%$ homology with $S$. griseus DNA also showed about $40 \%$ homology with $A$. globisporus. Therefore, it is concluded that the genomic Griseus group may be defined as the group having at least $56 \%$ homology with $S$. griseus ISP 5236 DNA and at least $47 \%$ homology (the majority has at least $59 \%$ homology) with $A$. globisporus ISP 5199 DNA.

The genomic Griseus group was diagrammatically divided into two large and four small subgroups, on the basis of the homology values obtained with the reference DNAs from Streptomyces griseus and Actinomyces globisporus. The legend to Fig. I shows the described species which are divided into subgroups and indicates the features of each species which are different from those of $S$. griseus. The DNA homology values of the three species in the subgroup I showed approximately 100 and $80 \%$ with $S$. griseus DNA and A. globisporus DNA, respectively. Actinomyces citreofluorescens differs from the other two in soluble pigments, utilization of $\mathrm{L}$-arabinose and rhamnose, and type of antibiotic produced (Shirling $\&$ Gottlieb, $1968 a, b)$. Similar differences within a subgroup were also found in the subgroups 2, 5 and 6 .

Further hybridizations were done to confirm that the largest subgroup (subgroup 5 in Fig. 1) consisted of closely related streptomycetes. The DNA sample of Streptomyces californicus ISP 5058, located at the centre of this subgroup 5, was used as the SD-DNA. Homology values of $88 \%$ or higher were obtained in Io of the 13 species tested while the three other species had homology values ranging from $7 \mathrm{r}$ to $83 \%$ (Table 6). These data apparently suggest that each subgroup in the genomic Griseus group represents an independent taxon, probably corresponding to a species. Each subgroup, however, consists of the designated species differing from one another in colour of vegetative mycelium, soluble pigments, utilization of L-arabinose and rhamnose, and type of antibiotic produced (legend to Fig. I). These findings suggest that these features are not suitable criteria for species identification in the genomic Griseus group, but may differentiate strains within a species.

The melanin-forming streptomycetes, such as Streptomyces cavourensis, Actinomyces cyaneofuscatus, and $S$. griseobrunneus, displayed fairly high homologies (at least $6 \mathrm{I} \%$ ) with $S$. griseus DNA (Table 5) and at least $90 \%$ homology with the DNA from $S$. californicus, a melanin-negative strain (Table 6). The lack of formation of melanoid pigments has been considered to be an important criterion for distinguishing the Griseus group by many researchers, with the notable exception of Pridham (1964) and Pridham \& Lyons (1965). However, from the data described above, the lack of melanin formation is not considered to be useful as a criterion for distinguishing the genomic Griseus group or a species within it. This conclusion is supported by the reports of Gregory \& Huang $(1964 a, b)$ that tyrosinase inheritance in $S$. scabies is controlled by a plasmid which can replicate faster than the chromosomal genome. On the other hand, we found that the colour of aerial mycelium and the utilization of three kinds of sugars were useful diagnostic characters for the identification of the genomic Griseus group (Table 5).

Reliability of the DNA homology values determined. The DNA homologies in reciprocal hybridizations and in the viomycin-producing strains were checked in Table 6 . The homo$\operatorname{logy}(67 \%)$ of Streptomyces griseus DNA to $S$. californicus DNA was similar to the homo$\operatorname{logy}(67 \%)$ of S. californicus DNA to S. griseus DNA. Similar results were also obtained for 
Table 6. DNA homologies of streptomycetes closely related to Streptomyces californicus ISP 5058

$\quad$ Source of IM-DNA
Streptomyces californicus 5058
S. vinaceus 5257
S. puniceus 5083
S. bikiniensis At-154
S. griseinus 5047
S. griseobrunneus 5066
S. cavourensis 5300
S. albidus 5320
S. microflavus 5331
Actinomyces badius 5139
S. pluricolorescens 5019
A. fluorescens 5203
S. alboviridis 5326
A. rubiginosohelvolus 5176
S. griseus 5236
A. globisporus 5199

$a$ Data derived from Tables 2 and 4. ${ }^{b}$ Data derived from Fig. I.

Source of SD-DNA

\begin{tabular}{|c|c|c|}
\hline \multicolumn{3}{|c|}{ Source of SD-DNA } \\
\hline $\begin{array}{l}\text { Streptomyces } \\
\text { californicus } \\
\text { ISP } 5058\end{array}$ & $\begin{array}{l}\text { S. griseus } \\
\text { ISP } 5236^{a}\end{array}$ & $\begin{array}{l}\text { Actinomyces } \\
\text { globisporus } \\
\text { ISP } 5199^{b}\end{array}$ \\
\hline 100 & 67 & 71 \\
\hline 98 & 64 & 69 \\
\hline 97 & 64 & 71 \\
\hline 96 & 56 & 74 \\
\hline 93 & 66 & 75 \\
\hline $9 \mathrm{I}$ & 64 & 66 \\
\hline 90 & 67 & 69 \\
\hline 90 & 64 & 67 \\
\hline 90 & 60 & 65 \\
\hline 89 & 68 & 77 \\
\hline 88 & 67 & 78 \\
\hline 83 & 70 & 74 \\
\hline 79 & 60 & 65 \\
\hline 71 & 56 & 71 \\
\hline 60 & 100 & 78 \\
\hline 75 & 70 & 100 \\
\hline
\end{tabular}

S. californicus-Actinomyces globisporus pair, 75 and $71 \%$, and for S. griseus-A. globisporus pair, 70 and $78 \%$. On the other hand, $S$. californicus, $S$. vinaceus and $S$. puniceus, producers of viomycin, were apparently a single taxon, showing at least $97 \%$ homology with $S$. californicus ISP 5058 DNA. Similarity of the DNA homology values in these three strains was also obtained by hybridizing with $S$. griseus ISP 5236 DNA, indicating 67, 64, and $64 \%$, respectively, and with $A$. globisporus ISP 5199 DNA, indicating $7 \mathrm{I}, 69$, and 7I \%, respectively. The reasonable agreement of homology values in these reciprocal hybridizations or in the DNAs of viomycin-producing strains by using the three reference DNAs attests to the reliability of the DNA homology values determined.

The DNA homologies of Streptomyces bikiniensis At-I54 and S. bikiniensis ISP 5235 with S. griseus DNA were of $56 \%$ (Table 3) and $104 \%$ (Table 4), respectively. Although both strains allegedly originated from the same strain IMRU 35I4 (Waksman), the features of ISP 5235 (Shirling \& Gottlieb, I968b) are very different from those given in the original descriptions (Johnston \& Waksman, 1948; Pridham \& Lyons, 1965) in the colour of aerial mycelium, the pattern of sugar utilization, and the formation of melanoid pigments. The features of At-I 54, on the other hand, are identical to those in the original descriptions. These facts suggest that, at some time, some error in transferring or labelling $S$. bikiniensis ISP $\mathbf{5 2 3 5}$ may have occurred.

The authors are indebted to T. Hasegawa of the Institute for Fermentation, Osaka, and A. Seino of the Kaken Chemical Co. Ltd for their kindness in supplying many cultures of streptomycetes. 


\section{REFERENCES}

BALDACCI, E. (1958). Development in the classification of actinomycetes. Giornale di Microbiologia 6, $10-27$.

Baldacci, E., Locci, R., Farina, G. \& VegetTI, G. (1963). Sulla mutabilitá indotta di alcuni caratteri di Streptomyces utilizzati nelle classificazioni. Giornale di Microbiologia 11, I37-166.

De Ley, J. \& Friedman, S. (1964). Deoxyribonucleic acid hybrids of acetic acid bacteria. Journal of Bacterio$\log y 88,937-945$.

Farina, G. \& Bradley, S. G. (1970). Reassociation of deoxyribonucleic acids from Actinoplanes and other actinomycetes. Journal of Bacteriology 102, 30-35.

Flaig, W. \& Kutzner, H. J. (1960). Beitrag zur Systematik der Gattung Streptomyces Waksman et Henrici. Archiv für Mikrobiologie 35, 105-138.

Friedman, S. \& De Ley, J. (1965). 'Genetic species' concept in Xanthomonas. Journal of Bacteriology 89, 95-100.

Gordon, R. E. \& Horan, A. C. (1968). A piecemeal description of Streptomyces griseus (Krainsky) Waksman and Henrici. Journal of General Microbiology 50, 223-233.

Gottlieb, D. \& Shirling, E. B. (1967). Cooperative description of type cultures of Streptomyces. I. The international streptomyces project. International Journal of Systematic Bacteriology 17, 31 5-322.

Gregory, K. F. \& HuANG, J. C. C. (1964a). Tyrosinase inheritance in Streptomyces scabies. I. Genetic recombination. Journal of Bacteriology 87, $1281-1286$.

Gregory, K. F. \& HuANG, J. C. C. (I964b). Tyrosinase inheritance in Streptomyces scabies. II. Induction of tyrosinase deficiency by acridine dyes. Journal of Bacteriology 87, 1287-1294.

Hesseltine, G. W., Benedict, R. G. \& Pridham, T. G. (1954). Useful criteria for species differentiation in the genus Streptomyces. Annals of the New York Academy of Science 60, 136-151.

HuANG, P. C. \& Rosenberg, E. (1966). Determination of DNA base composition via depurination. Analytical Biochemistry 16, 107-1 13.

HÜTTER, R. (1967). Systematik der Streptomyceten. Basel: S. Karger AG.

Johnston, D. B. \& Waksman, S. A. (1948). The production of streptomycin by Streptomyces bikiniensis. Journal of Bacteriology 55, 317-326.

Jones, D. \& SNEATH, P. H. A. (1970). Genetic transfer and bacterial taxonomy. Bacteriological Reviews 34, $40-8 \mathrm{r}$.

Mayama, M. (1959). A consideration on the classification of streptomycetes. Annual Report of Shionogi Research Laboratories (Japan) 9, I185-1212.

Monson, A. M., Bradley, S. G., Enquist, L. W. \& Cruces, G. (1969). Genetic homologies among Streptomyces violaceoruber strains. Journal of Bacteriology 99, 702-706.

Nom, R. (1960). On the classification of Streptomyces. Journal of Antibiotics 12, 236-247.

OKANISH, M. \& GREGORY, K. F. (1970). Methods for the determination of deoxyribonucleic acid homologies in Streptomyces. Journal of Bacteriology 104, 1086-1094.

PRIDHAm, T. G. (1958). A guide for the classification of streptomycetes according to selected groups. Applied Microbiology 6, 52-79.

Pridham, T. G. (1964). Taxonomic studies of Streptomyces griseus (Krainsky) Waksman et Henrici : a species comprising many subspecies. Antimicrobial Agents and Chemotherapy-1963, pp. 104-115. Detroit: American Society for Microbiology.

Pridham, T. G. \& Lyons, A. J. (1965). Further taxonomic studies on straight to flexuous streptomycetes. Journal of Bacteriology 89, $33 \mathrm{I}-342$.

Ravin, A. W. (1963). Experimental approaches to the study of bacterial phylogeny. American Naturalist 97 , 307-3I8.

Shirling, E. B. \& Gotrlieb, D. (1966). Methods for characterization of Streptomyces species. International Journal of Systematic Bacteriology 16, 313-340.

Shrrling, E. B. \& Gottlieb, D. (1968a). Cooperative description of type cultures of Streptomyces. II. Species description from first study. International Journal of Systematic Bacteriology 18, 69-189.

ShIrling, E. B. \& Gotrlieb, D. (1968 b). Cooperative description of type cultures of Streptomyces. III. Additional species descriptions from first and second studies. International Journal of Systematic Bacteriology 18, 279-392.

Shirling, E. B. \& Gotrlieb, D. (1969). Cooperative description of type cultures of Streptomyces. IV. Species description from the second, third and fourth studies. International Journal of Systematic Bacteriology, 19, 39I-5I2.

Waksman, S. A. \& Lechevalier, H. A. (1953). Guide to the Classification and Identification of the Actinomycetes and their Antibiotics. Baltimore: Williams and Willkins Co.

YAMAGUCHI, T. (1967). Similarity in DNA of various morphologically distinct actinomycetes. Journal of General and Applied Microbiology r3, 63-71. 